[Regular Paper]

\title{
The Role of Cobalt on Hydrodesulfurization and Hydrogenation of Dibenzothiophene and 4,6-Dimethyldibenzothiophene Catalyzed by $\mathrm{Co}-\mathrm{Mo} / \mathrm{Al}_{2} \mathrm{O}_{3}$
}

\author{
Qing Zhang, Weihua QIan, Satoshi Oshima, Atsushi Ishinara, and Toshiaki Kabe* \\ Dept. of Applied Chemistry, Tokyo University of Agriculture \\ and Technology, Nakacho, Koganei, Tokyo 184
}

(Received January 6, 1997)

\begin{abstract}
Hydrodesulfurization (HDS) of dibenzothiophene (DBT) and 4,6-dimethyldibenzothiophene (4,6DMDBT) and hydrogenation (HYD) of tetralin were investigated by use of a series of $\mathrm{Mo} / \mathrm{Al}_{2} \mathrm{O}_{3}$ and $\mathrm{Co}-\mathrm{Mo} / \mathrm{Al}_{2} \mathrm{O}_{3}$ catalysts in the temperature range from 240 to $340^{\circ} \mathrm{C}$ at $50 \mathrm{~atm}$. The activities of DBT and 4,6-DMDBT for hydrodesulfurization increased with increasing amount of cobalt added at lower $\mathrm{Co} / \mathrm{Mo}$ molar ratios (below 0.5). At higher Co/Mo molar ratios (above ca. 0.5), however, the promoting effect of cobalt for DBT increased only slightly. Compared with the case of DBT, the promoting effect of cobalt for HDS of 4,6-DMDBT decreased with increasing Co/Mo molar ratio, the maximum effect was attained when the ratio was 0.5. At the same molar ratio, the rate constants of the formation of biphenyls were approximately 20 times that of unpromoted $\mathrm{Mo} / \mathrm{Al}_{2} \mathrm{O}_{3}$, while the rate constants of the formation of cyclohexylbenzenes were approximately 4 times. Cobalt enhanced the activity of hydrodesulfurization more than that of hydrogenation. Further, the mode of formation of decalin and cyclohexylbenzenes was nearly the same and it was suggested that hydrogenation of tetralin and DBTs occurred on the same active sites.
\end{abstract}

\section{Introduction}

Hydrodesulfurization (HDS) of sulfur-containing petroleum fractions has long been one of the major catalytic operations in the petroleum industry1),2). Alumina-supported $\mathrm{Co}(\mathrm{Ni})-\mathrm{Mo}$ catalysts are most widely employed catalysts in these operations. Recently, deep desulfurization of light gas oil has become one of the global problems ${ }^{3) ~ 6)}$ that urgently needs to develop effective catalysts for such desulfurization; thus, various attempts have been made to improve the performance of conventional $\mathrm{Co}-\mathrm{Mo} / \mathrm{Al}_{2} \mathrm{O}_{3}$ catalysts7) 11). Recently, a number of studies with the use of some transition metals like $\mathrm{Ni}$ and $\mathrm{Ru}$ as promoters to alumina-supported $\mathrm{Mo}$ or $\mathrm{Co}-\mathrm{Mo}$ catalysts have been reported. In most of these studies, however, only benzothiophene (BT) or dibenzothiophene (DBT) was used as a typical sulfur-containing compound ${ }^{12), 13)}$ and HDS was often carried out at atmospheric pressure. There are few studies dealing with the promoting effect of Co on $\mathrm{Mo} / \mathrm{Al}_{2} \mathrm{O}_{3}$ catalysts for HDS of DBT 7) 11), and there are also only few studies dealing with the

* To whom correspondence should be addressed. promoting effect of Co on Co-Mo catalysts for HDS of 4,6-dimethyldibenzothiophene (4,6DMDBT) ${ }^{14) ~ 16)}$.

In order to elucidate the role of cobalt on $\mathrm{Co}-\mathrm{Mo} / \mathrm{Al}_{2} \mathrm{O}_{3}$ catalysts, various kinds of $\mathrm{Co}-\mathrm{Mo} /$ $\mathrm{Al}_{2} \mathrm{O}_{3}$ catalysts were prepared and $\mathrm{HDS}$ of DBT and 4,6-DMDBT were carried out. Moreover, during the HDS of DBTs, HYD of tetralin, which was used as a solvent, to decalin was also determined. Effects of the molar ratio of Co to Mo on HDS and HYD were investigated. Reaction mechanisms on HDS of DBT and 4,6-DMDBT were also estimated from product selectivity.

\section{Experimental Section}

\section{1. Materials}

Tetralin, used as a solvent, was of commercial GR grade (Kishida Chemicals). Dibenzothiophene (DBT) and 4,6-dimethyldibenzothiophene (4,6-DMDBT) were synthesized according to the method reported in the literature ${ }^{17), 18)}$. Purities of DBT and 4,6-DMDBT were $>99.5 \%$ and $>92 \%$, respectively. Hydrogen and hydrogen sulfide in hydrogen $\left(\mathrm{H}_{2} \mathrm{~S} 3 \%\right)$ were obtained from Tohei Chemicals. Cobalt nitrate hexahydrate (Co- 
$\left.\left(\mathrm{NO}_{3}\right)_{2} \cdot 6 \mathrm{H}_{2} \mathrm{O}\right)$ and ammonium heptamolybdate tetrahydrate $\left(\left(\mathrm{NH}_{4}\right)_{6} \mathrm{Mo}_{7} \mathrm{O}_{24} \cdot 4 \mathrm{H}_{2} \mathrm{O}\right)$ were of commercial GR grade (Kishida Chemicals).

\section{2. Preparation of Catalysts}

The catalysts used in this study were prepared by incipient wetness impregnation method. The $\gamma$ $\mathrm{Al}_{2} \mathrm{O}_{3}$ used as a support was supplied as 1/32-inch extrudates which were crushed and screened to 0.42 to $0.84 \mathrm{~mm}$ (20-35 mesh-sized) granules. The physical properties of the support were as follows: surface area $256 \mathrm{~m}^{2} / \mathrm{g}$; pore volume $(\mathrm{Hg}) 0.647$, $\left(\mathrm{H}_{2} \mathrm{O}\right) 0.712 \mathrm{ml} / \mathrm{g}$; and mean pore diameter $82 \AA$. Alumina supports were impregnated with aqueous solutions of cobalt nitrate hexahydrate and ammonium heptamolybdate tetrahydrate as required, but $\mathrm{pH}$ was not adjusted. After impregnation, the catalysts were dried at $120^{\circ} \mathrm{C}$ for $3 \mathrm{~h}$ and then calcined in air at $450^{\circ} \mathrm{C}$ for $5 \mathrm{~h}$. The catalysts were denoted as a series of Co-Mo catalysts consisting of $\mathrm{Co}(1.0)-\mathrm{Mo}(16.0), \mathrm{Co}(2.0)-$ $\mathrm{Mo}(16.0), \mathrm{Co}(3.0)-\mathrm{Mo}(16.0), \mathrm{Co}(4.0)-\mathrm{Mo}(16.0), \mathrm{Co}(5.0)-$ $\mathrm{Mo}(16.0)$, and $\mathrm{Co}(6.0)-\mathrm{Mo}(16.0)$. The numbers in parentheses indicated weight percentages of metal oxides of the catalysts. For example, $\mathbf{C o}(1.0)-$ $\mathrm{Mo}(16.0)$ means $\mathrm{CoO}=1.0 \mathrm{wt} \%$ and $\mathrm{MoO}_{3}=16.0$ $\mathrm{wt} \%$. The Co/Mo molar ratios of the series of above catalysts were $0.12,0.24,0.36,0.48,0.60$, and 0.72 , respectively.

\section{3. Apparatus and Procedure}

The reactor used was an $8 \mathrm{~mm}$-i.d. stainless steel tube packed with $0.2 \mathrm{~g}$ of catalyst particles mixed with quartz sand to a total volume of $2 \mathrm{~cm}^{3}$. After heating in air at $450^{\circ} \mathrm{C}$ for $24 \mathrm{~h}$, the catalyst was presulfided in a stream of $3 \% \mathrm{H}_{2} \mathrm{~S}$ in $\mathrm{H}_{2}$ under the following conditions: $30 \mathrm{l} / \mathrm{h}, \mathrm{l} \mathrm{atm}$, and at $400^{\circ} \mathrm{C}$ for $3 \mathrm{~h}$. It was then pressurized with hydrogen and a reactant solution was fed in using a pump (Kyowa Seimitsu KHD-16). Hydrodesulfurization was carried out under the following conditions: temperature, $240-340^{\circ} \mathrm{C}$; total pressure, $50 \mathrm{~atm}$; WHSV, $70 \mathrm{~h}^{-1}$; Gas/Oil, $1100 \mathrm{~N} l / l$; initial concentrations of DBTs, $0.1 \mathrm{wt} \%$. After HDS had reached a steady state $(3 \mathrm{~h})$, samples were collected from a gas-liquid separator. Subsequently, the reaction temperature was changed, and the samples were similarly collected after $2 \mathrm{~h}$.

\section{4. Analysis}

The samples collected were analyzed by gas chromatography (Shimadzu GC-9A) using a flame ionization detector, and all components in the sample were identified by comparing their retention times with those of standard compounds. Biphenyl (BP), cyclohexylbenzene (CHB), and 3,3'-dimethylbiphenyl (3,3'-DMBP) were commercially available. 3,3'-Dimethylcyclohexylbenzene (3,3'-DMCHB) was identified by a GC-MS
(QP2000/2000A) on the molecular weight from the reaction sample. In the gas chromatography, $0.1 \mu l$ of each sample was analyzed by using a $\mathrm{G}$ column 100 (i.d., $1.2 \mathrm{~mm}$; film thickness, $1.0 \mu \mathrm{m}$; length, $40 \mathrm{~m}$ ) programmed from 100 to $230^{\circ} \mathrm{C}$ (heating rate, $8^{\circ} \mathrm{C} / \mathrm{min}$; injection temperature, $270^{\circ} \mathrm{C}$; carrier gas, $\mathrm{N}_{2}$ ).

\section{Results}

\section{1. HDS Activity}

Hydrodesulfurization of DBT and 4,6-DMDBT was investigated in the range temperature from 240 to $340^{\circ} \mathrm{C}$. In the case of DBT, the products were mainly biphenyl (BP) and cyclohexylbenzene (CHB), while in the case of 4,6-DMDBT, they were 3,3'-dimethylbiphenyl (3,3'-DMBP) and 3,3'dimethylcyclohexylbenzene (3,3'-DMCHB).

Figure 1 shows the effect of $\mathrm{Co} / \mathrm{Mo}$ molar ratio on the total conversions of DBT, and the yields of $\mathrm{BP}$ and $\mathrm{CHB}$ by use of the catalysts of Co-Mo series. The conversion of DBT increased markedly at lower Co/Mo molar ratios, and it became constant at higher $\mathrm{Co} / \mathrm{Mo}$ molar ratios (above ca. 0.5). Figure 2 shows the effect of $\mathrm{Co} / \mathrm{Mo}$ molar ratio on the conversion of 4,6 -DMDBT, the yields of 3,3'-DMBP and 3,3'-DMCHB by using the same catalysts of the Co-Mo series. The conversion of 4,6-DMDBT increased up to the $\mathrm{Co} / \mathrm{Mo}$ ratio of 0.5 , and it decreased with further addition of cobalt. Moreover, at the $\mathrm{Co} /$ Mo molar ratio of 0.5 , the maximum conversion was observed.

The reaction rate constants of HDS and HYD were calculated by assuming that DBT, 4,6DMDBT, and tetralin conversions proceeded according to the pseudo-first order reaction. The reaction rate constants of HDS and HYD were calculated by Eq. (1).

$$
k_{\mathrm{HDS} \text { or } \mathrm{HYD}}=-\ln (1-x) F / W
$$

Where $k_{\mathrm{HDS}}$ or HYD is the rate constant of HDS or of HYD (mol/h-g-cat); $x$ is the conversion of DBT, 4,6-DMDBT, and tetralin; $F$ is the feed rate of reactant $(\mathrm{mol} / \mathrm{h}) ; W$ is the catalyst weight (g-cat).

The ratio of $k / k_{0}$ is plotted against $\mathrm{Co} / \mathrm{Mo}$ molar ratio as shown in Fig. 3 where $k$ denotes the rate constant of HDS on the Co-Mo catalyst, and $k_{0}$ denotes the rate constant of HDS on the Mo catalyst.

In HDS of DBT, formations of both $\mathrm{BP}$ and $\mathrm{CHB}$ were promoted with increasing $\mathrm{Co} / \mathrm{Mo}$ molar ratio. The $k / k_{0}$ value for $\mathrm{BP}$ was approximately 22 at 0.5 of $\mathrm{Co} / \mathrm{Mo}$ molar ratio of 0.5 , while that for $\mathrm{CHB}$ was approximately 4 . The $k / k_{0}$ values both for $\mathrm{BP}$ and $\mathrm{CHB}$ increased 


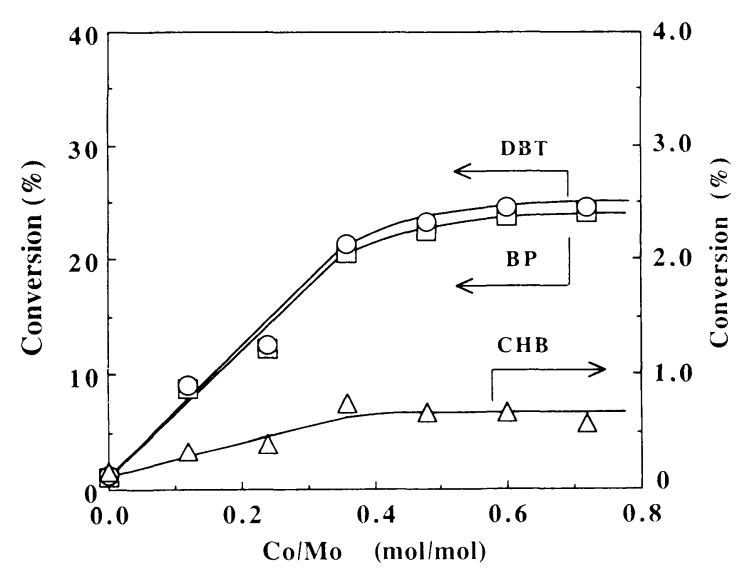

Fig. 1 Effect of Co/Mo Ratio on Conversion of DBT $\left(260^{\circ} \mathrm{C}\right)$

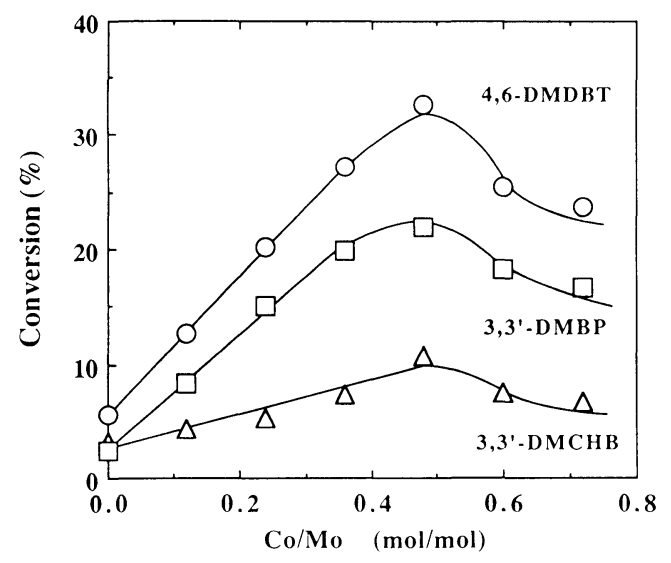

Fig. 2 Effect of Co/Mo Ratio on Conversion of 4,6$\operatorname{DMDBT}\left(340^{\circ} \mathrm{C}\right)$

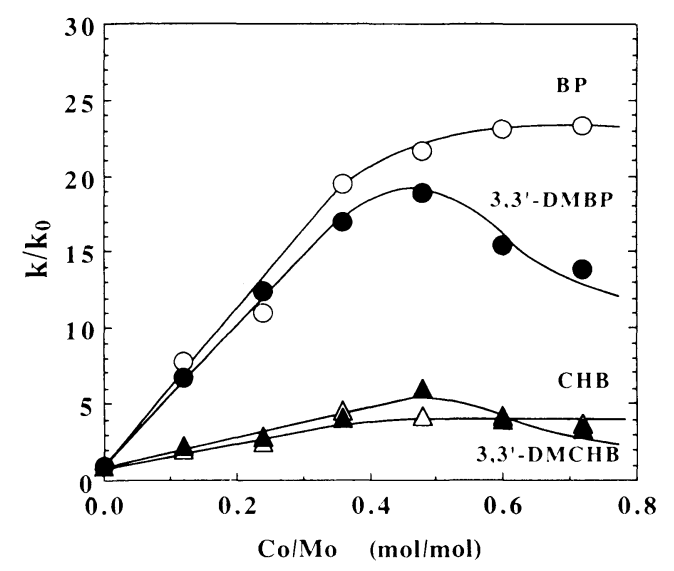

$k$ : the rate constant of HDS on Co-Mo catalyst,

$k_{0}$ : the rate constant of HDS on Mo catalyst.

Fig. 3 Relation of Co/Mo Ratio vs. $k / k_{0}$

only slightly when the Co/Mo molar ratio was above 0.5. In HDS of 4,6-DMDBT, similar results were obtained when the $\mathrm{Co} / \mathrm{Mo}$ molar ratio was

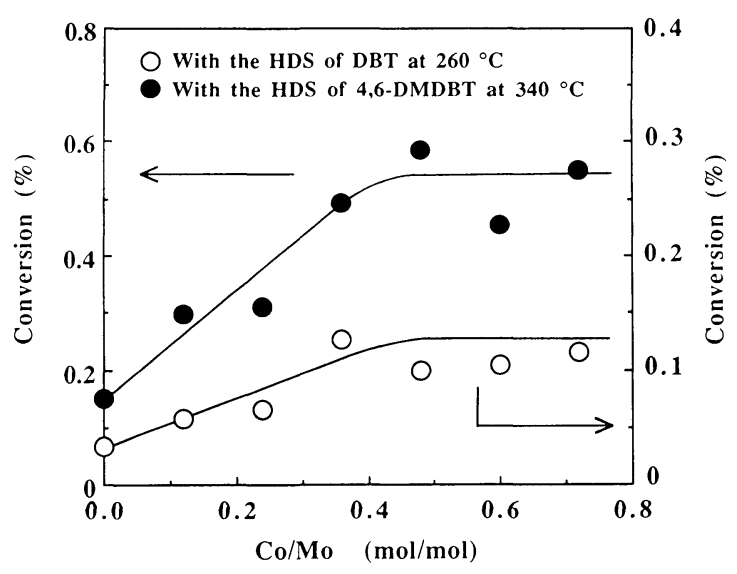

Fig. 4 Effect of Co/Mo Ratio on Conversion of Tetralin to Decalin

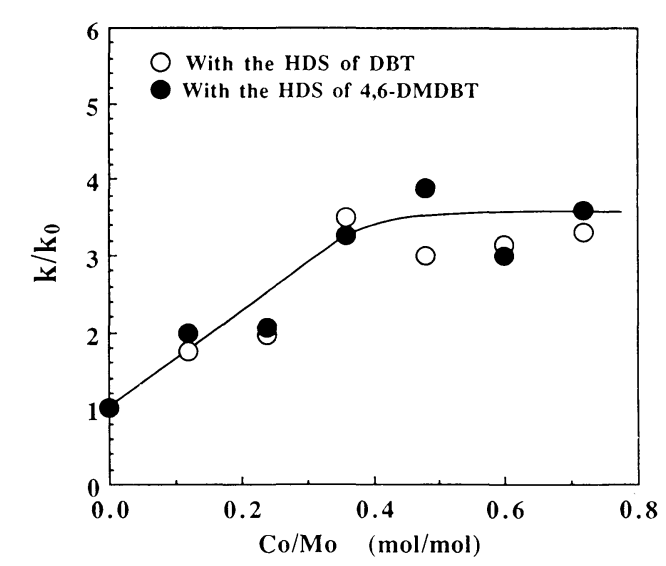

$k$ : the rate constant of HYD on Co-Mo catalyst, $k_{0}$ : the rate constant of HYD on Mo catalyst.

Fig. 5 Relation of Co/Mo Ratio vs. $k / k_{0}$

below 0.5. However, at higher $\mathrm{Co} / \mathrm{Mo}$ molar ratio $(\mathrm{Co} / \mathrm{Mo}>0.5)$, both $k / k_{0}$ values for $3,3^{\prime}$ DMBP and 3,3'-DMCHB decreased with increasing $\mathrm{Co} / \mathrm{Mo}$ molar ratio. These results indicated that the promoting effect of cobalt for DBT and 4,6-DMDBT was almost the same at lower $\mathrm{Co} / \mathrm{Mo}$ molar ratios, but at higher $\mathrm{Co} / \mathrm{Mo}$ molar ratios (above ca. 0.5) it was different for DBT and 4,6-DMDBT.

\section{2. HYD Activity}

In HDS of DBT and 4,6-DMDBT, tetralin was used as a solvent. During the reaction, tetralin was hydrogenated to decalin. Figure 4 shows the effect of $\mathrm{Co} / \mathrm{Mo}$ molar ratio on the conversion of tetralin to decalin during the HDS of DBT and 4,6DMDBT. The HYD reaction rate constants were calculated by Eq. (1), and the relation of $\mathrm{Co} / \mathrm{Mo}$ molar ratio $v s$. ratio of $k / k_{0}$ is shown in Fig. 5 . The HYD activity of tetralin during HDS of 


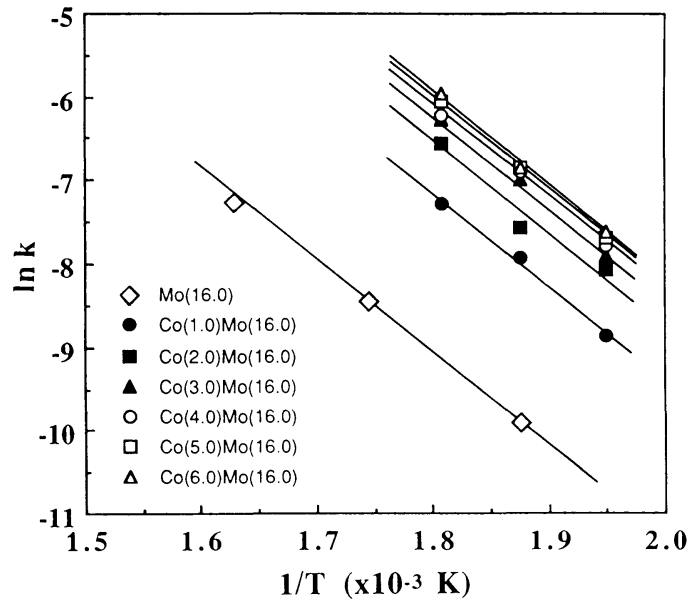

$k$ : HDS rate of DBT.

Fig. 6 Arrhenius Plot in the Reaction of DBT

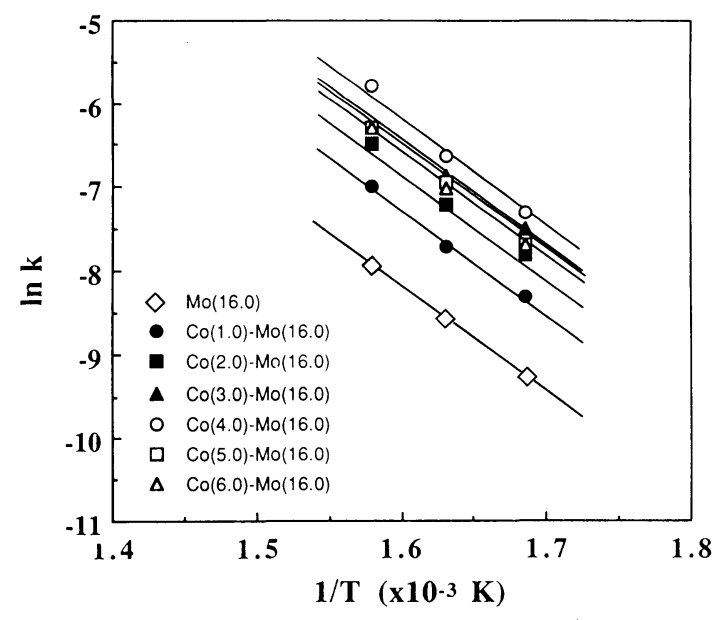

$k$ : HDS rate of 4,6-DMDBT.

Fig. 7 Arrhenius Plot in the Reaction of 4,6-DMDBT

DBT and 4,6-DMDBT increased at lower Co/Mo molar ratios, but at higher ratios (above ca. 0.5), $k / k_{0}$ values became 4 . This result was very similar to that of DBT conversion to $\mathrm{CHB}$, as shown in Fig. 3.

\section{Discussion}

Figure 6 shows the Arrhenius plots for HDS of DBT on unpromoted Mo (16.0) and cobaltpromoted $\mathrm{Mo} / \mathrm{Al}_{2} \mathrm{O}_{3}$ catalysts. For cobalt-promoted catalysts, their activation energies were $22 \pm 2 \mathrm{kcal} / \mathrm{mol}$, which were nearly the same as the activation energy of the unpromoted $\mathrm{Mo} / \mathrm{Al}_{2} \mathrm{O}_{3}$ catalyst. Figure 7 shows the Arrhenius plots for HDS of 4,6-DMDBT on unpromoted Mo(16.0) and cobalt-promoted $\mathrm{Mo} / \mathrm{Al}_{2} \mathrm{O}_{3}$ catalysts. Activation energies of the cobalt-promoted catalysts were $32 \pm 2 \mathrm{kcal} / \mathrm{mol}$, nearly the same as the activation energy of the unpromoted $\mathrm{Mo} / \mathrm{Al}_{2} \mathrm{O}_{3}$ catalyst. For both cases of DBT and 4,6-DMDBT, the increase in the catalytic activity by addition of cobalt was due to the increase in the frequency factor because the activation energy itself did not change significantly. Therefore, it is likely that the promoting effect of cobalt could be explained as a result of the formation of new active sites.

To understand the promoting effect of cobalt on HDS, several structural models have been proposed. The intercalation model was initially developed by Voorhoeve and Stuiver ${ }^{19)}$. They assumed that $\mathrm{Co}$ or $\mathrm{Ni}$ ions occupied the octahedral intercalation position between the slabs of $\mathrm{MoS}_{2}$ structure. Farragher and Cossee ${ }^{20)}$ later proposed a modified model in which intercalation was assumed to be restricted to the edge surfaces of the $\mathrm{MoS}_{2}$ lattice (pseudo-intercalation). Karroua et al.21), Zabala et al.22), and Goetsch et al. ${ }^{23)}$, showed that $\mathrm{Cog}_{8} \mathrm{~S}_{8}$ exhibited an promoting effect appreciably when it was intimately blended with $\mathrm{MoS}_{2}$. The contact synergy model was initially developed by Delmon and co-workers ${ }^{24), 25)}$. Unsupported catalysts showed the presence of bulk $\mathrm{MoS}_{2}$ and $\mathrm{Cog}_{9} \mathrm{~S}_{8}$, and it was proposed that such phases also existed in the supported catalysts. The promoting effect of Co was attributed to the result of the spillover of hydrogen from $\mathrm{Co}_{9} \mathrm{~S}_{8}$ to $\mathrm{MoS}_{2}$, thereby enhancing the intrinsic activity of the $\mathrm{MoS}_{2}{ }^{26)}$. These models were explained qualitatively rather than quantitatively; therefore, it is not clear at the present time whether the intercalation model or the contact synergy model is essential to the promoting effect.

The presence of an active phase, called "Co-Mo-S" phase, in supported and unsupported Co-Mo catalysts has recently been identified by Tops $\phi$ e and his co-workers ${ }^{7), 27) \sim 31)}$ using Mössbauer and IR spectroscopy. The combined results of activity and Mössbauer and IR spectroscopy studies of both supported and unsupported catalysts have shown that most of the catalytic activity is linked to the presence of the promoter atoms in Co-Mo-S. The in-situ studies showed that phases other than Co-Mo-S [e.g., $\mathrm{Co}_{9} \mathrm{~S}_{8}$ and $\mathrm{Co}$ in the alumina lattice $\left.\left(\mathrm{Co}: \mathrm{Al}_{2} \mathrm{O}_{3}\right)\right]$ might be present in typical alumina-supported Co-Mo catalysts (Fig. 8) $)^{7}$. Recently, the existence of the Co-Mo-S phase in the supported sulfided $\mathrm{Co}-\mathrm{Mo} / \mathrm{Al}_{2} \mathrm{O}_{3}$ catalysts has also been verified by $\mathrm{XPS}^{32)}$ and $\mathrm{EXAFS}^{8}$.

Recently, we have reported on the studies of HDS 


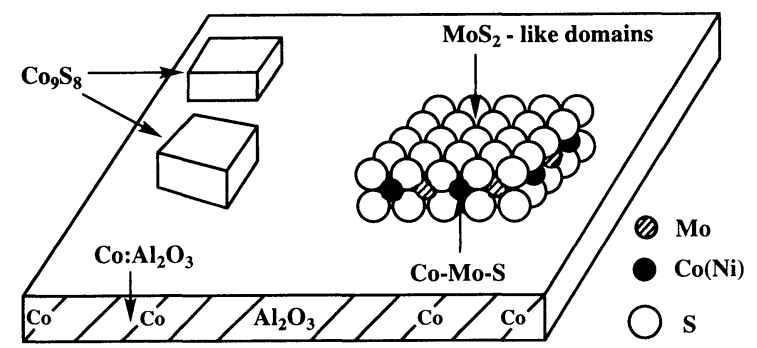

Fig. 8 Schematic View of the Different Phases in a Typical Alumina-supported Catalyst (adapted from ref. 7)

reaction of DBT on $\mathrm{Mo} / \mathrm{Al}_{2} \mathrm{O}_{3}$ and $\mathrm{Co}-\mathrm{Mo} / \mathrm{Al}_{2} \mathrm{O}_{3}$ catalysts using a ${ }^{35} \mathrm{~S}$ radioisotope tracer meth$\mathrm{od}^{33)}$ 36). The behavior of sulfur on the catalysts was investigated, and a difference in the behaviors of the catalysts was observed. The promoting role of cobalt was attributed to the cobalt atom that permits the sulfur present in the $\mathrm{Co}-\mathrm{Mo}-\mathrm{S}$ phase a greater mobility. In the case of $\mathrm{Mo} / \mathrm{Al}_{2} \mathrm{O}_{3}$, we have also reported that molybdenum was dispersed on the alumina support by a monolayer of molybdena up to $16 \mathrm{wt} \%$ and that HDS activity increased with increasing content of molybdena ${ }^{36)}$. In the case of $\mathrm{Co}-\mathrm{Mo} / \mathrm{Al}_{2} \mathrm{O}_{3}$, cobalt is dispersed on $\mathrm{Mo} / \mathrm{Al}_{2} \mathrm{O}_{3}$ and combined with the molybdenum to form a new and highly active site such as $\mathrm{Co}-\mathrm{Mo}-\mathrm{S}$ phase. From Fig. 3, the formation of both BPs and $\mathrm{CHBs}$ was promoted with an increase in the $\mathrm{Co} / \mathrm{Mo}$ molar ratio at a lower $\mathrm{Co} / \mathrm{Mo}$ level $(\mathrm{Co} /$ $\mathrm{Mo}<0.5$ ), suggesting that cobalt could be dispersed on $\mathrm{Mo} / \mathrm{Al}_{2} \mathrm{O}_{3}$ with a lower cobalt content $(\mathrm{Co} /$ Mo $<0.5)$ and that two molybdenum atoms could load one cobalt atom successfully. However, when the cobalt content is higher $(\mathrm{Co} / \mathrm{Mo}>0.5)$, the surplus cobalt may cover the highly active Co-Mo-S sites. In this case, compounds with methyl groups, such as 4,6-DMDBT, which cause steric hindrance, cannot approach the highly active sites; thus, HDS of 4,6-DMDBT and HYD of aromatic rings in 4,6-DMDBT will be inhibited. As a result, at higher $\mathrm{Co} / \mathrm{Mo}$ molar ratios $(\mathrm{Co} /$ Mo $>0.5), k / k_{0}$ values for both 3,3'-DMBP and 3,3'DMCHB decreased with increasing Co/Mo molar ratio as shown in Fig. 3. However, in the case of DBT, although the surplus cobalt may cover the highly active sites, the DBT can still approach the highly active $\mathrm{Co}-\mathrm{Mo}-\mathrm{S}$ sites because it does not have a methyl group. That is, if large masses of $\mathrm{Cog}_{8} \mathrm{~S}_{8}$ which are formed from surplus cobalt on alumina exist near the Co-Mo-S sites as in Fig. 8, the approach of 4,6-DMDBT to the Co-Mo-S sites would be more difficult than that of DBT. According to the literature, the HDS rate of thiophene approached the maximum in the range of $\mathrm{Co} /$ Mo ratio from 0.5 to 1.0 , but in the range of $\mathrm{Co} /$ Mo higher than 1.0, the rate decreased or was not affect $\left.\left.{ }^{30}, 31\right), 37\right)$ 39). In this paper, the rate of HDS of DBT was constant and the rate of HDS of 4,6-DMDBT decreased at $\mathrm{Co} /$ Mo ratios above 0.5. It seems that the HDS of three ring 4,6dimethyldibenzothiophene as well as dibenzothiophene is more sensitive to the change in the catalyst structure brought about by addition of cobalt than that of thiophene.

In the case of HDS of DBT and 4,6-DMDBT, the $k / k_{0}$ values for BPs formation in Fig. 3 were approximately 20 at $\mathrm{Co} / \mathrm{Mo}$ molar ratio 0.5 . In contrast, in the case of HYD of tetralin, the $k / k_{0}$ values for decalin formation shown in Fig. 5 were approximately 4 at Co/Mo molar ratio 0.5 . These results clearly indicated that cobalt enhanced the HDS activity more significantly than HYD activity. On the other hand, the behaviors of HYD of tetralin and HYD of DBT to CHB were very similar. The $k / k_{0}$ values for decalin formation in Fig. 5 and for CHBs formation in Fig. 3 were both approximately 4 at Co/Mo molar ratio 0.5. These results showed that the HYD of tetralin and HYD of DBT occurred on the same active sites.

\section{Conclusion}

The activity of hydrodesulfurization of DBT and 4,6-DMDBT increased with increasing amount of cobalt added at $\mathrm{Co} / \mathrm{Mo}$ molar ratio below 0.5. At higher Co/Mo molar ratios (above ca. 0.5), however, the addition of cobalt increased the activity of HDS of DBT but slightly. In contrast, further addition of cobalt decreased the activity of HDS of 4,6-DMDBT. The rate constants of formation of $\mathrm{BPs}$ at the $\mathrm{Co} / \mathrm{Mo}$ molar ratio of 0.5 were approximately 20 times higher than those for the unpromoted Mo catalyst, while the constants of $\mathrm{CHBs}$ at the $\mathrm{Co} / \mathrm{Mo}$ molar ratio of 0.5 were approximately 4 times higher. The rate constants of formation of decalin at the $\mathrm{Co} / \mathrm{Mo}$ molar ratio of 0.5 were also approximately 4 times higher than those for the unpromoted Mo catalyst. The cobalt enhanced the HDS activity greater than HYD activity. Moreover, it seemed that HYD of tetralin and DBT occurred on the same active sites.

\section{Acknowledgments}

A part of this work has been carried out as a research project of The Japan Petroleum Institute commissioned by the Petroleum Energy Center with the subsidy of the Ministry of International Trade and Industry. 


\section{Nomenclatures}

$\begin{array}{ll}\text { HDS } & : \text { Hydrodesulfurization } \\ \text { HYD } & : \text { Hydrogenation } \\ \text { BT } & : \text { Benzothiophene } \\ \text { DBT } & : \text { Dibenzothiophene } \\ \text { 4,6-DMDBT } & : \text { 4,6-Dimethyldibenzothiophene } \\ \text { BP } & : \text { Biphenyl } \\ \text { CHB } & : \text { Cyclohexylbenzene } \\ \text { 3,3'-DMBP } & : \text { 3,3'-Dimethylbiphenyl } \\ \text { 3,3'-DMCHB }: 3,3 \text { '-Dimethylcyclohexylbenzene } \\ \text { XPS } & : \text { X-Ray Photoelectron Spectroscopy } \\ \text { EXAFS } & : \text { Extended X-ray Absorption Fine Structure }\end{array}$

\section{References}

1) Gates, B. C., Katzer, J. R., Schuit, G. C. A., "Chemistry of Catalytic Processes," McGraw-Hill, New York (1979), p. 390.

2) Topsфe, H., Clausen, B. S., Massoth, F. E., "Hydrotreating Catalysis," Springer, Berlin (1996), p. 111

3) Kabe, T., Ishihara, A., Tajima, H., Ind. Eng. Chem. Res., 31, 1577 (1992).

4) Kabe, T., Ishihara, A., Zhang, Q., Tsutsui, H., Sekiyu Gakkaishi, 36, (6), 467 (1993)

5) Ishihara, A., Tajima, H., Kabe, T., Chem. Lett., 1992, 669.

6) Zhang, Q., Ishihara, A., Yashima, H., Qian, W., Tsutsui, H., Kabe, T., Sekiyu Gakkaishi, 40, (1), 29 (1997).

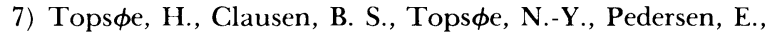
Ind. Eng. Chem. Fundam., 25, 25 (1986).

8) Bouwens, S. M. A. M., van Veen, J. A. R., Koningsberger, D. C., de Beer, V. H. J., Prins, R., J. Phys. Chem., 95, 123 (1991).

9) Hangenbach, G., Courty, Ph., Delmon, B., J. Catal., 23, 295 (1971).

10) Voorhoeve, R. J. H., J. Catal., 23, 236 (1971).

11) Yamada, M., Sekiyu Gakkaishi, 36, (2), 85 (1993).

12) Ishihara, A., Itoh, T., Hino, T., Nomura, M., Qi, P., Kabe, T., J. Catal., 140, 184 (1993).

13) Ishihara, A., Kabe, T., Ind. Eng. Chem. Res., 32, (4), 753 (1993).

14) Kabe, T., Ishihara, A., Zhang, Q., Appl. Catal., A. Gen., 97, Ll (1993).

15) Zhang, Q., Ishihara, A., Kabe, T., Sekiyu Gakkaishi, 39, (6), 410 (1996).
16) Zhang, Q., Qian, W., Ishihara, A., Kabe, T., Sekiyu Gakkaishi, 40, (3), 185 (1997).

17) Gilman, H., Jacoby, A. L., J. Org. Chem., 4, 108 (1938).

18) Gerdil, R., Lucken, E. A. C., J. Am. Chem. Soc., 87, 213 (1965).

19) Voorhoeve, R. J. H., Stuiver, J. C. M., J. Catal., 23, 228 (1971).

20) Farragher, A. L., Cossee, P., "Proc. 5th Int. Congress Catalysis," Palm Beach, North-Holland, Amsterdam (1973), p. 1301

21) Karroua, M., Matralis, H., Grange, P., Delmon, B., J. Catal., 139, 371 (1993).

22) Zabala, J. M., Mainil, M., Grange, P., Delmon, B., React. Kinetic Catal. Lett., 3, 285 (1975).

23) Goetsch, D. A., Carver, J. C., Seiver, R. L., Sawyer, W. H., 8th North American Meeting of the Catalysis Society, Philadelphia, May 1-4, 1983.

24) Delmon, B., ACS. Div. Pet. Chem. Prepr., 22, 503 (1977).

25) Hagenbach, G., Courty, Ph., Delmon, B., J. Catal., 31, 264 (1973).

26) Delmon, B., Bull. Soc. Chim. Belg., 88, 979 (1979).

27) Tops $\phi$ e, H., Clausen, B. S., Catal. Rev.-Sci. Eng., 26, 395 (1984).

28) Tops $\phi$ e, H., Candia, R., Tops $\phi$ e, N.-Y., Clausen, B. S., Bull. Soc. Chim. Belg., 93, 783 (1984).

29) Tops $\phi$ e, H., Clausen, B. S., Candia, R., Wivel, C., Morup, S., J. Catal., 68, 433 (1981).

30) Wivel, C., Candia, R., Clausen, B. S., Morup, S., Tops $\phi$, H., J. Catal., 68, 453 (1981).

31) Topsфe, N.-Y., Topsфe, H., J. Catal., 84, 386 (1983).

32) Lee, D. K., Lee, T. H., Lee, I. C., Park, S. K., Bse, S. Y., Kim, C. H., Woo, S. I., J. Catal., 159, 219 (1996).

33) Kabe, T., Qian, W., Ogawa, S., Ishihara, A., J. Catal., 143, 239 (1993)

34) Kabe, T., Qian, W., Ishihara, A., J. Phys. Chem., 98, (3), 912 (1994).

35) Kabe, T., Qian, W., Wang, W., Ishihara, A., Catal. Today, 29, 197 (1996).

36) Qian, W., Zhang, Q., Okoshi, Y., Ishihara, A., Kabe, T., Faraday Trans., 93, (9), 1821 (1997).

37) Boudart, M., Arrieta, J. S., Dalla Betta, R., J. Am. Chem. Soc., 105, 6501 (1983).

38) Derouane, E. G., Pedersen, E., Clausen, B. S., Gabelica, Z., Candia, R., Topsфe, H., J. Catal., 99, 253 (1986).

39) Topsфe, N.-Y., Topsфe, H., J. Catal., 77, 293 (1982). 
要旨

\section{$\mathrm{Co}-\mathrm{Mo} / \mathrm{Al}_{2} \mathrm{O}_{3}$ を用いたジベンゾチオフェンおよび \\ 4,6-ジメチルジベンゾチオフェンの水素化脱硫反応および水素化反応における Co の役割}

張慶, 銭 衛 華, 大島 悟, 石原 篤, 加部利明

東京農工大学工学部物質生物応用化学科, 184 東京都小金井市中町 2-24-16

$\mathrm{Co} / \mathrm{Mo}$ 比の異なる $\mathrm{Co}-\mathrm{Mo} / \mathrm{Al}_{2} \mathrm{O}_{3}$ 触媒を調製し, ジベンゾ チオフェン（DBT）拉よ゙ 4,6-ジメチルジベンゾチオフェン (4,6-DMDBT) の脱硫反応を $240 \sim 340^{\circ} \mathrm{C}, 50 \mathrm{~atm} の$ 条件下 で行った。 Co/Mo 比が 0.5 以下の場合では, 触媒の DBT お よび 4,6-DMDBT の脱硫活性に対するCo の添加効果はほほ 同様であり, いずれの転化率も Co/Mo 比の増加に比例して増 加した。Co/Mo 比が 0.5 以上になると, DBT の転化率はわず かに増加した。これに対し，4,6-DMDBT の転化率は減少した。 Co の最大添加効果は $\mathrm{Co} / \mathrm{Mo}$ 比が 0.5 のところに現れた。無
添加 $\mathrm{Mo} / \mathrm{Al}_{2} \mathrm{O}_{3}$ 触媒に対し, $\mathrm{Co} / \mathrm{Mo}$ 比が 0.5 の触媒ではビ フェニル類の生成速度は 20 倍向上し, シクロヘキシルベンゼ ン類の生成速度は 4 倍向上した。また, テトラリンからデカリ ンへの生成速度も 4 倍向上した。Co は触媒の脱硫活性も水素 化活性も向上させるが，脱硫活性をより大きく向上させること がわかった。さらに，シクロヘキシルベンゼン類の生成反応と デカリンの生成反応の挙動が似ていることから，ジベンゾチオ フェン類の水素化反応とテトラリンの水素化反応は同一活性点 上で起こっていると考えられる。

\section{Keywords}

Hydrodesulfurization, Hydrogenation, Alkyldibenzothiophenes, Cobalt molybdenum catalysts, Alumina 